\title{
Hubungan Relijiusitas dengan Self Awareness Mahasiswa Program Studi Bimbingan Penyuluhan Islam (Konseling) UAI
}

\author{
M. Yudi Ali Akbar ${ }^{1}$, Rizqi Maulida Amalia ${ }^{2}$, Izzatul Fitriah ${ }^{3}$ \\ ${ }^{1,2,3}$ Program Studi Bimbingan Penyuluhan Islam (Konseling), Fakultas Psikologi dan Pendidikan, Universitas \\ Al Azhar Indonesia, Jalan Sisingamangaraja, Kompleks Masjid Agung Al Azhar, Kebayoran Baru, Jakarta \\ Selatan 12110
}

Penulis untuk Korespondensi/E-mail: yudi_ali@uai.ac.id

\begin{abstract}
Abstrak - Penelitian ini hendak melihat hubungan antara relijiusitas dengan self awareness pada mahasiswa/i prodi BPI (konseling) UAI. Dimana self awareness merupakan kecerdasan pemahaman diri sesuai dengan situasi dan kondisi, yang memiliki faktor penunjang bagi penguatan self awareness. Keberagamaan seseorang menjadi faktor penentu bagi bagaimana bersikap, kepeduliaannya dan lainnya. Dalam ajaran agama mengajarkan untuk berperilaku terpuji baik bagi diri maupun sesama. Data pada penelitian ini dengan kuisioner skala relijiusitas dan self awarenes yang telah mengalami uji validitas dan reabilitas. Penelitian dengan sample 84 mahasiswa/i prodi BPI yang merupakan jumlah populasi aktif ini memberikan hasil bahwa adanya hubungan yang signifikan antara relijiusitas dengan self awareness dengan derajat yang lemah. Penelitian ini sebagai awalan dari penelitian berikutnya yang lebih mendalam baik dari sisi variabel maupun sample dan alat analisis.
\end{abstract}

Abstract - This research aims to see the relation between religiosity with self awareness on student of BPI (counseling) program. Where self awareness is the intelligence of self-understanding in accordance with the situation and conditions, which has a supporting factor for the strengthening of self awareness. One's religiousness becomes the decisive factor for how to behave, his or her care and others. In the teachings of religion teaches to behave well for both themselves and others. The quantitative ata in this study with religious scale and self awareness who have meet the validity and reliability test. The research with sample of 84 students of BPI study program which is the number of active population gives result that there is a significant relation between religiosity and self awareness with weak degree. This research is a prefix of subsequent research in more depth both in terms of variables and samples and analysis tools.

Keywords - Religiosity, Self Awarenes, College Student

\section{PENDAHULUAN}

$\mathrm{M}$ ahasiswa bukan hanya seorang yang terdaftar di perguruan tinggi. Bukan hanya seorang yang akan melanjutkan studinya ke jenjang pendidikan yang lebih tinggi, tetapi, mahasiswa merupakan seorang yang terdidik dan semestinya memiliki perbedaan tingkah laku maupun moral dari yang lain.

Data dari Badan Pusat Statistik menunjukkan jumlah mahasiswa tahun 2014/2015 mencapai 316,904 dari seluruh perguruan tinggi swasta di Indonesia. Angka yang tinggi, begitupun dengan harapan lingkungan masyarakat terhadap prilaku afektif yang menunjukkan bahwa mahasiswa merupakan remaja yang terpelajar dan mampu merubah lingkungan serta peka terhadap lingkungannya.

Dari harapan lingkungan kepada mahasiswa tentu akan sama dengan mahasiswa yang memiliki kepandaian dari segi pengetahuan agama. Begitupun pada mahasiswa bimbingan penyuluhan Islam yang sejatinya akan bergerak dalam bidang sosial. Terlebih lagi dengan pemahaman agama yang menjadi nilai lebih dari prodi ini. Tentunya akan menjadi suatu hal yang akan dilihat dan 
sebagai gambaran dari mahasiswa program studi Bimbingan Penyuluhan Islam.

Seorang konselor perlu kepekaan sosial dalam membaca situasi dan kondisi klien. Begitupun saat terjun di lapangan dalam hal ini lingkungan. Baik dari lingkungan terkecil yaitu keluarga, teman, lingkungan sekitar rumah, maupun lingkungan yang cangkupannya lebih luas lagi. Oleh sebab itu dengan pengetahuan yang dimiliki oleh mahasiswa tersebut diharapkan masyarakat tidak ragu untuk mencari solusi terkait persoalan yang dihadapi di tengah-tengah masyarakat kepada mereka.

Hasil dari latar belakang di atas, merumuskan beberapa masalah yang akan dibahas selanjutnya, seperti :

a. Seberapa tinggi tingkat religiusitas yang dimiliki mahasiswa bimbingan penyuluhan islam ?

b. Adakah hubungan antara religiusitas dengan self-awareness mahasiswa bimbingan penyuluhan islam?

\section{TINJAUAN PUSTAKA}

\section{Religiusitas}

Religiusitas diwujudkan dalam berbagai sisi kehidupan manusia. Aktivitas keberagaman bukan hanya terjadi ketika seseorang melakukan perilaku ritual (beribadah khusus) saja tetapi juga ketika melakukan aktivitas kehidupan lainnya. Bukan hanya berkaitan dengan aktivitas yang dapat dilihat mata, tetapi juga aktivitas yang tidak tampak dan terjadi dalam hati sanubari seseorang.

Secara bahasa religiusitas (religiosity) berasal dari kata religius (religious), religius merupakan kata sifat (adjective) dari religion. Menurut kamus Oxford (372-373), kata religion memiliki dua definisi, pertama, belief in and worship of God or gods. Yaitu sebuah kepercayaan dan peribadatan pada Tuhan atau dewa-dewa. Kedua, particular system of faith and worship based on such belief. Yaitu bagian dari sistem kepercayaan dan peribadatan yang berdasarkan keyakinan. Adapun kata religious menurut definisi kamus Oxford adalah, adjective of religion, (religious) of a person believing in and practicing religion. Yaitu sifat keagamaan yang ada pada seseorang, atau keberagamaan seseorang dalam meyakini dan mengamalkan agama.
Bellah dalam Brian J. Zinnbauer \& Kenneth I. Pargament (2005: 23) mendefinisikan religiusitas adalah seperangkat bentuk-bentuk simbolik dan aksi-aksi simbolik yang menghubungkan manusia dengan kondisi yang paling suci pada eksistensinya. Dengan definisi ini dapat dipahami bahwa religiusitas bersifat simbolik saja.

Religiusitas adalah tingkat pengetahuan seseorang terhadap agama yang dianutnya serta suatu tingkat pemahaman yang menyeluruh terhadap agama yang dianutnya (Glock \& Stark, 1970; Zinbaueur \& Pargament, 2005).

\section{Dimensi Religiusitas}

Religiusitas meliputi berbagai sisi atau dimensi. Religiusitas terdiri dari lima dimensi sebagai berikut:

- Dimensi ideologi yaitu tingkatan sejauh mana seseorang menerima hal-hal yang dogmatik dalam agamanya. Misalnya kepercayaan tentang sifat-sifat Tuhan, adanya malaikat, surga, dan neraka.

- Dimensi ritual yaitu tingkatan sejauh mana seseorang mengerjakan kewajiban-kewajiban ritual dalam agamanya. Misalnya sholat, puasa, mengaji, dan membayar zakat serta ibadah haji.

- Dimensi pengalaman yaitu perasaan atau pengalaman keagamaan yang pernah dialami dan dirasakan. Misalnya merasa dekat dengan Tuhan, merasa takut berbuat dosa atau merasa bahwa doa-doanya dikabulkan Tuhan.

- Dimensi konsekuensi yaitu dimensi yang mengukur sejauh mana perilaku seseorang dimotivasi oleh ajaran agamanya di dalam kehidupan sosial. Misalnya apakah ia mengunjungi tetangganya yang sedang sakit, menolong orang yang kesulitan dan mendermakan hartanya.

- Dimensi intelektual yaitu seberapa jauh pengetahuan seseorang tentang ajaran - ajaran agamanya, terutama yang ada dalam kitab suci.

Sedangkan dimensi religiusitas menurut Kendler, dkk (2003) ada tujuh yaitu:

a. General religiosity bagaimana hubungan seseorang dengan Tuhannnya.

b. Social religiosity bagaimana seseorang membina hubungan dengan sesama penganut agamanya.

c. Involved God keyakinan akan keterlibatan Allah SWT dalam segala urusan manusia.

d. Forgiveness menggambarkan kepedulian dan saling memaafkan. 
e. God as judge menggambarkan kekuasaan Allah SWT.

f. Unvengefulness perilaku seseorang yang tidak dendam kepada orang lain.

g. Thankfulness bagaimana seseorang menggambarkan rasa syukur.

\section{Faktor Religiusitas}

Jalaluddin (2010) menjelaskan ada beberapa faktor yang mempengaruhi perkembangan religiusitas seseorang antara lain:

- Faktor internal yaitu faktor yang muncul dari dalam diri seseorang yang mendorong seseorang untuk tunduk kepada Allah SWT.

- Faktor eksternal yaitu faktor yang meliputi lingkungan masyarakat. Lingkungan keluarga dimana keluarga adalah sebuah sistem kehidupan sosial terkecil dan merupakan tempat seseorang anak pertama kali belajar mengenai berbagai hal salah satunya adalah mengenai religiusitas.

Mahasiswa merupakan masa pertumbuhan manusia dari remaja ke dewasa, untuk itu peneliti juga mengambil teori religiusitas yang menjadi faktor pengaruh bagi remaja. Menurut Thouless (2000) ia mengemukakan empat faktor yang mempengaruhi perkembangan religiusitas remaja yaitu:

a Pengaruh pendidikan atau pengajaran dan berbagai tekanan sosial, termasuk pendidikan dari orangtua, tradisi-tradisi sosial, tekanan lingkungan sosial yang disepakati oleh lingkungan itu

b Berbagai pengalaman yang membentuk sikap keagamaan, terutarna pengalaman-pengalaman mengenai keindahan, keselarasan dan kebaikan di dunia ini, konflik moral dan pengalaman emosi beragam;

c Kebutuhan yang belurn terpenuhi terutama kebutuhan keamanan, cinta kasih, harga diri serta adanya ancarnan kematian

d Berbagai proses pemikiran verbal atau faktor intelektual.

\section{Kesadaran Diri (Self-Awareness) \\ Definisi Kesadaran Diri}

Menurut konsep Suryamentaram yang dikutip oleh Prihartanti (2004), bahwa mawas diri adalah sebagai cara latihan (memilah-milah) rasa sendiri dengan rasa orang lain untuk meningkatkan kemampuan menghayati rasa orang lain sebagai manifestasi tercapainya pertumbuhan dan perkembangan kepribadian yang sehat dan sejahtera. Self awareness ialah kecerdasan mengenai alasan-alasan dari pemahaman diri sendiri. Kesadaran diri adalah pokok yang penting untuk menunjukkan kejelasan dan pemahaman tentang perilaku diri. Kesadaran diri juga merupakan kecerdasan dimana seseorang akan dapat menempati dirinya pada situasi dan kondisi tertentu dan kesadaran tentang dirinya dan apa yang harus ia lakukan.

Wawasan tambahan diperoleh dengan model empat diri Jendela Johari :

a. The Open Self (Diri yang Terbuka)

Diketahui oleh kita dan orang lain. Informasi, tingkah laku, sikap, perasaan, hasrat, motivasi, dan ide. Tapi kita terbiasa membuka diri kita kepada beberapa orang saja, dan kepada orang yang lain kita cenderung menutup diri. Padahal terbuka itu dibutuhkan dalam komunikasi.

b. The Blind Self (Diri yang Buta)

Seluruh hal mengenai diri kita yang orang lain ketahui namun cenderung kita abaikan. Mulai dari kebiasaan sepele sampai penting, seperti bagaimana kita memiliki ekspresi yang meluap-luap, kebiasaan memegang hidung saat marah, dan sebagainya.

c. The Hidden Self (Diri yang Tersembunyi)

Segala hal yang kita ketahui tentang diri kita namun merupakan rahasia bagi orang lain. Termasuk segala hal yang tidak ingin kita tunjukkan.

Dari penjabaran di atas, dapat kita simpulkan bahwa kesadaran diri adalah kemampuan diri dalam mengetahui apa yang ia rasakan dan lakukan serta apa penyebab dan tujuan dari apa yang ia lakukan dan rasakan serta bagaimana seharusnya ia bersikap terhadap dirinya maupun lingkungannya.

\section{Bentuk Kesadaran Diri}

Perlu diketahui bahwa tokoh psikologi yakni Baron dan Byrn (2005) mereka berpendapat bahwa self awareness memiliki beberapa bentuk diantaranya

- Self awareness subjektif adalah kemampuan dirinya untuk membedakan dirinya dari lingkungan fisik dan sosialnya. Yaitu bagaimana ia harus bersikap yang membuat orang bisa menilai dirinya berbeda dengan yang lainnya.

- Self awarenes subjektif adalah kapasitas seseorang untuk menjadi objek perhatiannya sendiri, kesadaran akan keadaan pikirannya dan mengetahui bahwa bahwa ia tahu dan mengingat bahwa ia ingat. Maksudnya ialah 
dimana pribadi sadar akan tugas dan tanggung jawabnya.

- Self awareness simbolik adalah kemampuan seseorang untuk membentuk sebuah konsep abstrak dari diri melalui bahasa kemampuan seseorang untuk berkomunikasi, menjalin hubungan, menentukan tujuan mengevaluasi hasil dan membangun sikap yang berhubungan dengan diri dan membelanya terhadap komunikasi yang mengancam.

Menurut konsep Suryamentara (2004), bahwa mawas diri adalah sebagai cara latihan Milah Mlahake (memilah-milah) rasa sendiri dengan rasa orang lain untuk meningkatkan kemampuan menghayati rasa orang lain sebagai manifestasi tercapainya pertumbuhan dan perkembangan kepribadian yang sehat dan sejahtera. Hasil penelitian Yosshimich mendapati bahwa pemahaman diri melalui tahapan mawas diri mampu menunjukkan bahwa pada diri seseorang ada elemen kunci yang sangat menentukan bahagia tidaknya seseorang, elemen ini adalah elemen yang selalu stabil, tenang, serta damai, dan elemenelemen yang berubah-ubah, senantiasa berubah serta selalu berusaha menuruti keinginannya sendiri.

\section{METODOLOGI PENELITIAN}

\section{Jenis Penelitian}

Penelitian ini menggunakan pendekatan kuantitatif, yaitu untuk mengetahui adanya hubungan antar variabel Independen dengan variabel dependen. Responden dalam penelitian ini adalah mahasiswamahasiswi Program Studi BPI (Konseling).

Pada penelitian ini pengumpulan data dilakukan dengan menggunakan kuesioner dimana yang digunakan dalam penelitian ini adalah kuesioner skala religiusitas dan self-awareness.

\section{Definisi Konseptual}

\section{Self-Awareness}

Kesadaran diri menurut Bradberry Greaves (2005) adalah kemampuan untuk memahami emosi diri sendiri secara tepat dan akurat dalam berbagai situasi secara valid dan reliable. Bagaimana reaksi emosi diri di saat menghadapi suatu peristiwa yang memancing emosi, sehingga seseorang dapat memahami respon emosi dirinya sendiri dari segi positif maupun negatif. Orang yang memiliki kesadaran diri yang tinggi memiliki sikap positif di dalam menjalani kehidupan. Dia memiliki pikiran positif (positive thinking) di dalam menilai sebuah fenomena kehidupan betapapun buruknya fenomena tersebut dimata orang lain.

Self awareness ialah kecerdasan mengenai alasanalasan dari pemahaman diri sendiri. Maka dapat disimpulkan bahwa self-awareness atau kesadaran diri bukan hanya peka terhadap diri dan emosinya, tetapi juga peka pada keadaan, lingkungan termasuk pada orang lain.

\section{$\underline{\text { Religiusitas }}$}

Religiusitas adalah tingkat pengetahuan seseorang terhadap agama yang dianutnya serta suatu tingkat pemahaman yang menyeluruh terhadap agama yang dianutnya (Glock \& Stark, 1970; Zinbauer\& pargament, 2005).

Sedangkan dimensi religiusitas menurut Kendler, dkk (2003) ada tujuh, dan menggambarkan bagaimana hubungan seseorang dengan Allah, hubungan seorang dengan sesama manusia, dan bagaimana ia memiliki kepribadian yang berdasarkan pada agamanya. Jadi, penulis menyimpulkan bahwa religiusitas ialah suatu pemahaman agama yang terpancarkan dari pribadi seseorang mulai dari hubungan ia dengan tuhan, hubungan ia dengan orang lain serta prilakunya terhadap diri sendiri.

Disini kami akan melihat tentang bagaimana seseorang mahasiswa paham akan nilai-nilai dalam agama islam dan bagaimana ia menjalankan perintah Allah dengan beribadah serta mengimplementasikan nilai islam dalam kehidupan sehari hari.

\section{Lokasi Penelitian}

Penelitian ini dilangsungkan di Universitas AlAzhar Indonesia, Kebayoran baru, Jakarta Selatan.

\section{Populasi dan Sample}

Populasi merupakan komponen penelitian atau objek dari penelitian ini. Tetapi pupulasi pada penelitian kali ini hanya bersifat terbatas. Maka populasi yang yang akan diteliti ini adalah mahasiswa Program studi bimbingan penyuluhan islam konseling sesuai dengan judul dan lebih diperkecil lagi hanya di lingkungan Universitas AlAzhar Indonesia.

Sample adalah sebagian kecil dari populasi yang akan diteliti dan akan mewakili populasi penelitian. Teknik pengambilan sampling pada penelitian ini adalah menggunakan simple random 
sampling. Teknik ini diambil untuk mempermudah penelitian. Sample dalam penelitian kali ini total sample yang diambil dari 84 mahasiswa BPI Universitas Al-Azhar Indonesia.

\section{Teknik Analisis Data}

Data yang didapat dari hasil penelitian adalah berupa angka yang didapatkan dari hasil penyebaran quisioner kepada mahasiswa mahasiswi BPI. Pada analisis dilakukan uji normalitas, uji homogenitas, dan uji hipotesis.

a Uji Normalitas

Uji normalitas ini digunakan untuk mengetahui data terdistribusi normal.

b Uji Hipotesis 1

Untuk menguji hipotesis pertama pada penelitian ini digunakan uji linieritas yaitu untuk mengetahui adanya hubungan religiusitas terhadap self-awareness mahasiswa.

\section{PEMBAHASAN}

Dari total 15 item pertanyaan untuk skala Self Awareness, ada 9 item pertanyaan yang dinyatakan baik validitas nya dan dapat digunakan untuk mengukur skala self awareness dalam penelitian ini.

Hasil uji reabilitas dan validitas skala religiuistas menunjukkan cronbach alpha 0.835, yang menunjukkan bahwa skala ini realible untuk digunakan pada penelitian. Dari total item 43, ada 34 item yang memenuhi kriteria keabsahan.

Data penelitian telah melewati uji normalitas dan uji linieritas, dengan hasil uji normalitas A.symp sig .2-tailed nilainya 0.097. Berarti bahwa nilai $0.097>0,05$ yang berarti bahwa data berdistribusi normal. Adapun untuk nilai uji linearitas sebesar < 0.05 yang menunjukkan bahwa antara variabel independen dengan variabel dependent terdapat hubungan yang linier dalam kasus penelitian ini.

Hasil penelitian terhadap 84 responden yang merupakan mahasiswa/i prodi BPI (konseling) UAI, untuk menjawab hipotesis penelitian

Tabel 1. Hasil Uji Statistik Hubungan antar Variabel Relijiusitas dengan Variabel Self Awareness

\begin{tabular}{|c|c|c|c|c|c|c|c|c|c|}
\hline \multirow[b]{2}{*}{ Model } & \multirow[b]{2}{*}{$\mathrm{R}$} & \multirow[b]{2}{*}{$\begin{array}{c}\mathrm{R} \\
\text { Square }\end{array}$} & \multirow[b]{2}{*}{$\begin{array}{l}\text { Adjusted R } \\
\text { Square }\end{array}$} & \multirow[b]{2}{*}{$\begin{array}{l}\text { Std. Error of the } \\
\text { Estimate }\end{array}$} & \multicolumn{5}{|c|}{ Change Statistics } \\
\hline & & & & & $\begin{array}{l}\text { R Square } \\
\text { Change }\end{array}$ & $\begin{array}{c}\mathrm{F} \\
\text { Change }\end{array}$ & df1 & df2 & $\begin{array}{l}\text { Sig. F } \\
\text { Change }\end{array}$ \\
\hline 1 & ,381(a) &, 145 & $\overline{0}, 090$ & 4,50952 &, 145 & 2,643 & 5 & 78 &, 029 \\
\hline
\end{tabular}

Tabel di atas menunjukkan nilai $\mathrm{R}$ adalah 0.381 yang berarti bahwa hubungan antar variabel relijiusitas dengan variabel self awareness ada hubungan yang lemah. Adapun nilai Sig. F change adalah 0.029 yang berarti bahwa adanya hubungan antar variabel relijiusitas dengan self awareness yang signifikan dengan derajat keeratan hubungan yang rendah antar keduanya.

Relijiusitas yang dimiliki seseorang ada kaitannya dengan self awareness yang dimiliki. Berdasarkan teori Gold \& Stark, (1970); Zinnbauer \& Pargament, (2005) bahwa ada beberapa dimensi dalam relijiusitas yang menjadi komponen dalam variabel sehingga menguatkan.

Tabel di atas menunjukkan nilai $\mathrm{R}$ adalah 0.381 yang berarti bahwa hubungan antar variabel relijiusitas dengan variabel self awareness ada hubungan yang lemah. Adapun nilai Sig. F change adalah 0.029 yang berarti bahwa adanya hubungan antar variabel relijiusitas dengan self awareness yang signifikan dengan derajat keeratan hubungan yang rendah antar keduanya.

Religiusitas yang dimiliki seseorang ada kaitannya dengan self awareness yang dimiliki. Berdasarkan teori Gold \& Stark, 1970; Zinnbauer \& Pargament, 2005) bahwa ada beberapa dimensi dalam relijiusitas yang menjadi komponen dalam variabel sehingga menguatkan. Hal ini sejalan dengan penelitian Rusydi (2012) tentang relijiusitas dan kesehatan mental. Bahwasannya ada korelasi yang signifikan antara relijiusitas dengan kesehatan mental pada jamaah tabligh sebagai responden penelitian. 


\section{PENUTUP}

\section{Kesimpulan}

Dilihat dari hasil penelitian, peneliti dapat menyimpulkan bahwa religiutas mahasiswa pada penelitian ini dapat meningkatkan self awareness. Hal ini disebabkan dimensi keberagamaan meningkatkan kesadaran diri, lebih peka sebagaimana agama adalah untuk menata kehidupan manusia agar lebih baik, bahagia dan selamat dunia akhirat. Hal ini dapat dibuktikan oleh hasil penelitian menujukan bahwa $14,5 \%$ dari hail tersebut relijiusitas berpengaruh pada self awareness.

Dalam penelitian ini dengan sample pada mahasiswa prodi BPI UAI, menunjukkan bahwa ada hubungan positif antara relijiusitas yang dimiliki responden dengan self awareness nya. Hasil demikian menjadi rujukan pada langkahlangkah peningkatan self awarenss dengan cara peningkatan relijiusitas.

\section{Saran}

Untuk penelitian selanjutnya dengan variabel lainnya yang mendukung bagi peningkatan self awareness dan pada objek yang beragam, maka peneliti dapat memberikan beberapa saran dan rekomendasi dari hasil penelitian diantaranya:

Pertama, bagi pengelola pendidikan dalam hal ini Perguruan Tinggi untuk memberikan perhatian lebih dalam usaha peningkatan relijiusitas melalui kegiatan-kegiatan keagamaan.

Kedua, bagi peneliti selanjutnya peneliti memberi saran agar dapat menambah jumlah repsonden yang dijadikan sampel dari peneliti yang telah dilakukan, serta menambah dan melengkapi teori yang belum ada dari beberapa referensi lain.

\section{DAFTAR PUSTAKA}

[1] S.Arikunto, Metodologi Penelitian, Penerbit PT. Rineka Cipta. Jakarta, 2002.

[2] T. Bradberry \& J. Greaves, 2005, Emotional Intelligence, San Diego: Talent Smart, 2005.

[3] R. A. Baron, \& D. Byrne, Psikologi social jilid 1. Jakarta: Erlangga 2005 Calhoum Caplin.

[4] Nanik Prihartanti, Kepribadan Sehat Menurut Konsep Suryomentaram, Surakarta : Muhammadiyah Unversity Press, 2004.

[5] Y.C.Glock, \& Stark, Religion and society in tension. San Francisco: Rand McNally, 1970

[6] Kendler, K. S., Liu, X.-Q., Gardner, C. O., McCullough, M. E., Larson, D., \& Prescott, C. A. (2003, Maret). Dimension of religiosity and their relationship to lifetime psychiatric and substance use disorders. Religiosity and Psychiatric Disorders.

[7] J. Rahmat, Psikologi Agama. Jakarta: PT Raja Grafindo Persada, 2010.

[8] H. Thouless, Pengantar Psikologi Agama. Jakarta: Rajawali Press, 2000.

[9] JURNAL PSIKOLOGI, 1998, NO. 155 - 64 Religiusitas Remaja: Stud1 Tentang Kehidupan Beragama Di Daerah Istimewa Yogyakarta*) Tina Afiatin

[10] Sugiyono, Metode Penelitian Kuantitatif Kualitatif dan R\&D, Bandung: Alfabeta, 2007.

[11] Oxford University Press, Oxford Learner's Pocket Dictionay: Fourth Edition (Oxford: Oxford University Press, 2009)

[12] Brian J. Zinnbauer \& Kenneth I. Pargament, Religiousness and Spirituality, in Handbook of the Psychology of Religion and Spirituality, ed. Raymond F. Paloutzian \& Crystal L. Park (New York: The Guildford Press, 2005), 23.

[13] www.bps.go.id 